(C) 2019 by the Arizona Board of Regents on behalf of the University of Arizona. This is an Open Access article, distributed under the terms of the Creative Commons Attribution licence (http://creativecommons. org/licenses/by/4.0/), which permits unrestricted reuse, distribution, and reproduction in any medium, provided the original work is properly cited.

\title{
SPATIAL DISTRIBUTION AND PROBLEMS IN THE INTERPRETATION OF RADIOCARBON DATES OF THE SUNGIR SITE, RUSSIA
}

\author{
Taisiya Soldatova
}

Institute of Pre- and Protohistory, Department Old World and Asian Cultures, Friedrich-Alexander-University Erlangen-Nürnberg (FAU), Kochstrasse 4/18, 91054 Erlangen, Germany

\begin{abstract}
The Upper Paleolithic open-air site Sungir is located in the central Russian Plain. The blank production of the lithic industry is characterized by parallel reduction with flakes being the main blank type. The tool assemblage has two components: archaic types (Mousterian-like) on the one hand and Upper Paleolithic types on the other. The available data does not allow for a confident determination of the chronological position of the Sungir site, nor does it enable researchers to distinguish different stages of human occupation. The horizontal distribution of the dated samples demonstrates the almost complete absence of radiocarbon $\left({ }^{14} \mathrm{C}\right)$ dates for household features identified at the site (fireplaces, fire and ritual pits, large accumulations of bones, etc.). In addition, the vertical distribution of ${ }^{14} \mathrm{C}$ dates in the rather thick cultural layer points to the exposure of the site to solifluction.
\end{abstract}

KEYWORDS: Aurignacian, Early Upper Paleolithic, radiocarbon chronology, spatial distribution, Streletskian culture, Sungir site.

\section{INTRODUCTION}

The Upper Paleolithic open-air site Sungir is located on the central Russian Plain on the high left bank of the Klyazma River $\left(56^{\circ} 11^{\prime} \mathrm{N}\right.$, and $40^{\circ} 30^{\prime} \mathrm{E}$; see Figure 1; Bader 1978). Sungir was discovered in 1956. For 24 field seasons (1957-2004) an expedition under the leadership of O.N. Bader, N.O. Bader, and L.A. Mikhajlova explored over 4000 square meters of the site area. Some authors define the cultural layer as "cultural soil," because remains are to a large extent mixed and can be found through the whole depth of the soil. The thickness of the findbearing layer is up to $1 \mathrm{~m}$ (Bader 1978). The archaeological remains consist of stone and bone objects, faunal remains, fireplaces, firepits, and ritual pits. A complicated burial complex with two graves with four burials (six individuals in all) was also found at the site.

The lithic industry is characterized by parallel reduction. The most numerous blanks are flakes. The tool assemblage has two components. The first one has a rather archaic (Mousterian-like) character and consists of side-scrapers, triangular bifacial points with a concave base, and projectile points. The second part of the tool set is from the Upper Paleolithic and includes end-scrapers (single end-scrapers, circular end-scrapers, oval end-scrapers, etc.), burins (truncation burins, straight burins, etc.), punches and pièces esquillées, etc. (Bader 1978; Seleznyov 2004). An analogous industry has been discovered at numerous Streletskian culture sites in the middle of Don River. Due to the presence of triangular bifacial points with concave bases, the Sungir site has been classified as a transitional cultural phase of the Early Upper Paleolithic (Bader 1978; Marom et al. 2012: 6879), a hypothesis that sometimes has been underlined by the emphasis that the industry combines elements of the Aurignacian and the Szeletian (Bader 1978; Grigoriev 1990; White 1993).

The fauna of the Sungir site contains numerous remains of reindeer (Rangifer tarandus), mammoth (Mammuthus primigenius), horse (Equnus caballus $\mathrm{cf}$. Taubachensis Frend), polar fox (Alopex lagopus), wolf (Canis lupus), and others (Gromov 1966).

Author email: soldatova.tais@gmail.com. 


\section{T Soldatova}

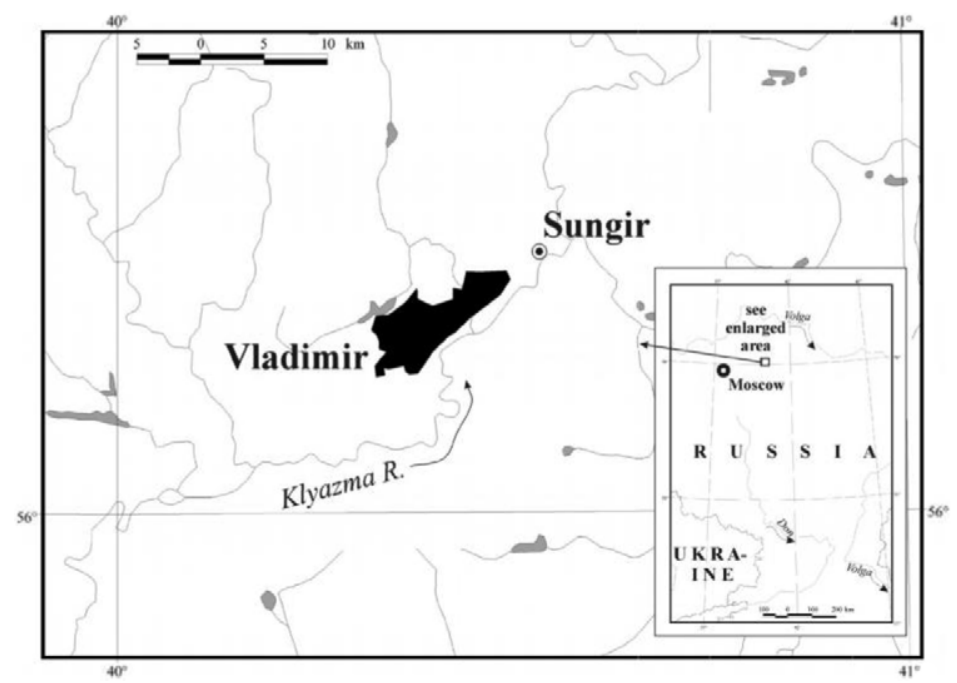

Figure 1 Location of the Sungir site (Kuzmin et al. 2004).

Interpretation of the radiocarbon $\left({ }^{14} \mathrm{C}\right)$ dates from Sungir is one of the most debated issues in the discussion of the peculiarities of the site, with consequences for the view of the cultural layer as well as for the establishment of different periods of human occupation there (e.g., Alekseeva and Bader 2000; Dobrovolskaya et al. 2012; Marom et al. 2012; Kuzmin et al. 2014). It has been repeatedly noted that ${ }^{14} \mathrm{C}$ dates on human bones from the famous burials do not correspond well to one other and, at the same time, do not correlate with ${ }^{14} \mathrm{C}$ dates obtained on samples from the cultural layer (e.g. Alekseeva and Bader 2000). There are unresolved questions about the presence of two cultural layers at Sungir as well as the question of the general chronological position of the site. In various publications, Sungir is attributed to the Early or Middle Upper Paleolithic, and some argue that it belongs to the Eastern Gravettian (e.g. Dobrovolskaya et al. 2012; Marom et al. 2012; Soldatova 2017). At the same time, the lithic industry, with its combination of both archaic (Mousterian-like) and Upper Paleolithic tools, as well as the study of the bone, antler, and ivory industry, as conducted by the author of the current article, lead to the conclusion of the possible influence of the Early Aurignacian culture (Bader 1978; Seleznyov 2004; Soldatova 2017).

\section{MATERIAL AND METHODS}

The area of Sungir was investigated within the boundaries of three excavation blocks, which have their own grid system. The thickness of the cultural layer varies from 0.5 to $1 \mathrm{~m}$, with a greater thickness noted in the upper parts of the slope (Bader 1998; see Figure 2). In the course studying the statistical data, E.D. Kaverzneva concluded that the "initial" cultural layer was no more than $40 \mathrm{~cm}$ thick (Kaverzneva 1985). According to Kaverzneva, the difference between the thickness of the original cultural layer and its current state is associated with the influence of solifluction (Kaverzneva 1985, 2004). On the other hand, in a 1998 publication, the concept of the effect of solifluction on the cultural layer was called into question (Lavrushin and Spiridonova 1998). Instead, Yu.A. Lavrushin and E.A. Spiridonova developed the idea of widespread gravitational processes in the slope area of the Sungir site and concluded that the deformations described before as resulting from solifluction are associated with the lower parts 
SE

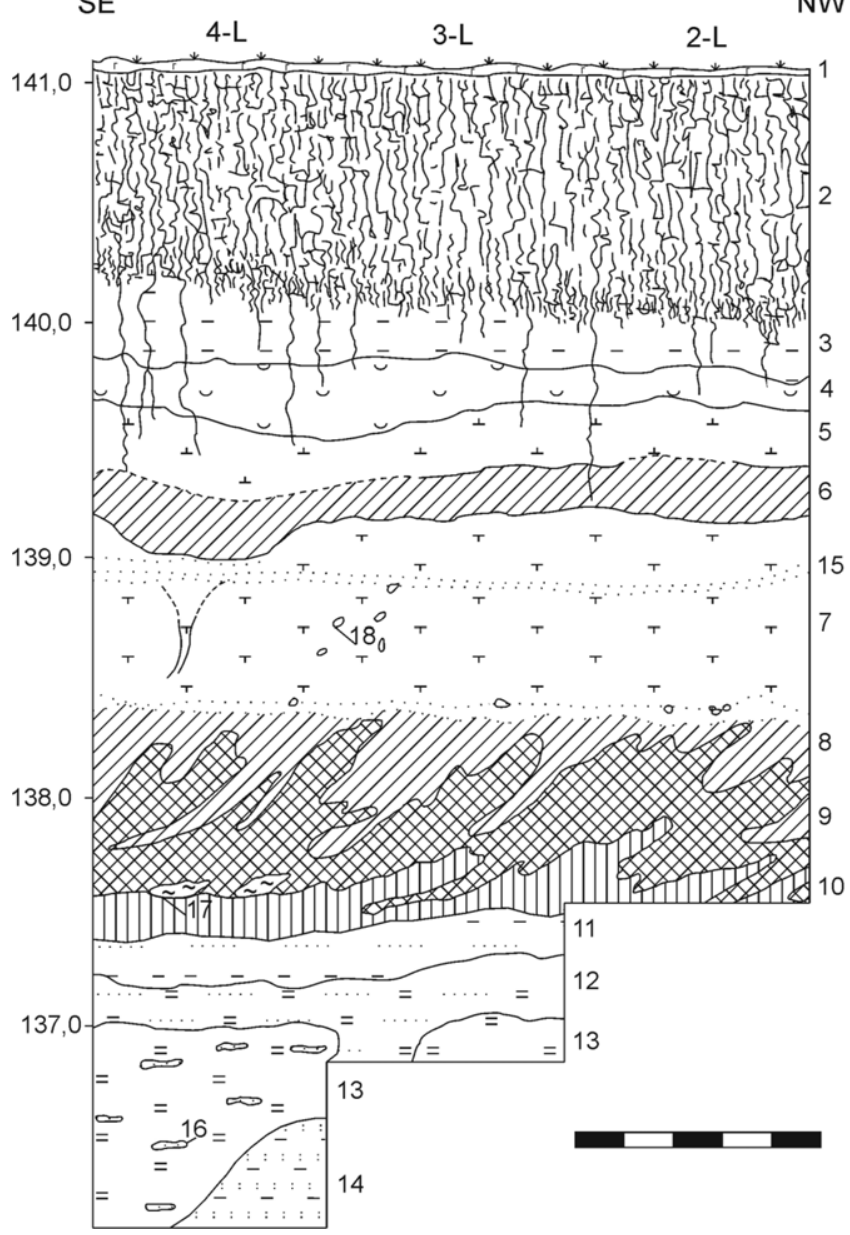

Figure 2 Stratigraphy of the Sungir site (Bader 1998): 1) modern soil; 2) columnar brown loam; 3 ) bottom of columnar loam denser structure; 4) loam scaly structure with a significant amount of carbonate inclusions; 5) light loam, yellowish; 6) upper buried soil; 7) loam with numerous whitish carbonate and point inclusions of manganese; 8) light-gray humus loam, contains rare cultural remains; 9) dark-gray humus loam contains cultural remains; 10) light loam; 11) clay loam, grayish, with inclusions of manganese; 12) clay loam, bright orange color with a lot of manganese; 13) clay loam, bright, with horizontal stripes, light sand and a lot of manganese; 14) bright red loam; 15) ortsand horizon; 16) carbonate; 17) varved clay; 18) sandy clay.

of landslide blocks, not with solifluction processes (Lavrushin and Spiridonova 1998: 196). It should be noted that the analysis of the original collection of Sungir by T. Soldatova showed that the objects have no signs of rounding or movement, which speaks for the absence of strong solifluction activities in the zone where bone, antler, and ivory artifacts occur (Soldatova 2017).

Other problems derive from the excavation method applied by O.N. Bader (1978), who was not only confronted with a problem that is was impossible to fix-the paleosurface of the find-bearing layer-but at the same had to find a way to cope with the thickness of the 


\section{T Soldatova}

latter. He decided to subdivide the cultural layer during the field research into arbitrary levels. The levels were counted from a zero-line determined by the level of the first occurrence of finds within the layer. The thickness of the arbitrary levels depended on the frequency of cultural remains and averaged between 15 and $20 \mathrm{~cm}$, but sometimes arbitrary levels of $5-10 \mathrm{~cm}$ were excavated separately (Bader 1978).

Although O.N. Bader notes that the level of first stratigraphical appearance of material culture and fauna "was on average about $20 \mathrm{~cm}$ above the visually definable, well-defined fossil soil horizon" (Bader 1978: 25, 61; translation by the author), the level of the soil itself would have varied throughout the entire excavation area. Thus, it is not possible to establish the exact depth of the finds. Consequently, the stratigraphic analysis is only possible by using the arbitrary levels in which certain items were excavated. In addition, the correlation of arbitrary levels between different excavation blocks is hampered by the fact that they start at different zero-lines, the latter resulting from the depth of the first occurence of archaeological remains. Furthermore, it is impossible to fully analyze the the spatial distribution. Although the locations of particular finds in a specific area of each square were documented during the excavations, not all plans of each excavation block are available in the field reports of O.N. Bader stored the Archive of the Institute of Archaeology Russian Academy of Sciences.

In excavation block No. I, arbitrary levels were not always distinguished (Bader 1978: 25). Moreover, excavation block No. I was located in an area that was dug up in the course of the development of a brick plant's quarry "by several longitudinal faces for the entire length of the quarry to a depth of $4 \mathrm{~m}$," which partially disturbed the cultural layer (Bader 1978: 10; translation by the author). In this regard, the arbitrary levels of this excavation block cannot be correlated with the levels of other excavation blocks. Due to the aforementioned reasons, the material from excavations of block No. I was not used in the original consideration of the stratigraphy of Sungir (Bader 1978; Kaverzneva 1985, 2004).

Notwithstanding the aforementioned shortcomings, O.N. Bader (1978) combined all finds from each excavation block into a single system of arbitrary levels. Due to the large size of the excavated area, it is - for the moment-not possible to solve this problem, and it is questionable if any long-term project would be able to do so. Therefore, the present article uses the (overall problematic) state of the art, which is the three-dimensional fixation of archaeological remains within the excavation cubatur. It follows that conclusions based on the stratigraphical information at hand must be treaed with caution, especially when it comes to large-scale interpretations.

${ }^{14} \mathrm{C}$ dates on animal bones and charcoal were produced from the cultural layer of Sungir (Sulerzhitsky et al. 2000). The direct AMS ${ }^{14} \mathrm{C}$ dates were published by Pettitt and Bader (2000), followed by Kuzmin et al. (2004), and more recently by Marom et al. (2012) and Dobrovolskaya et al. (2012) (Kuzmin et al. 2014: 451). Thirty-four ${ }^{14} \mathrm{C}$ dates on the mammal bones-mammoth, horse, and reindeer-were obtained from the Sungir cultural layer. Twenty ${ }^{14} \mathrm{C}$ dates came from human bones from the Sungir burials, and four ${ }^{14} \mathrm{C}$ dates stemmed from charcoal sampled from the cultural layer and human burials (one sample each) and the soil (two samples). Samples were dated by several laboratories: the Geological Institute of the Russian Academy of Sciences (lab code GIN), the University of Arizona (lab code AA), the University of Groningen (lab code GrA), the University of Oxford (lab codes OxA, OxX), and University of Kiel (lab code KIA). 
It is also necessary to note the dearth of the archival data linked to the ${ }^{14} \mathrm{C}$ samples. Of the $60{ }^{14} \mathrm{C}$ dates available, 20 were obtained on the samples from the human burials. Thirtythree dates come from the cultural layer and were measured in the laboratory of the Geological Institute of the Russian Academy of Sciences, Moscow. Of these, only $16{ }^{14} \mathrm{C}$ dates are clearly linked to a specific excavation unit (square). For four additional ${ }^{14} \mathrm{C}$ dates, it was possible for the author of the present article to identify their origin after consulting the field reports of O.N. Bader. For five ${ }^{14} \mathrm{C}$ dates, which were measured during an experimental phase when the laboratory was established, no information exists except that the samples came from the Sungir site. In the remaining eight cases, the number of the square is not clearly indicated. Recent investigations of the available data in the logbook of the Geological Institute by the current author allowed for the correction of some information given in the publication by L.D. Sulerzhitsky (Alekseeva and Bader 2000), who partly analyzed the location of the samples dated in the laboratory of the Geological Institute of the Russian Academy of Sciences. For example, in two cases, Sulerzhitsky did not publish the excavated square, although it is recorded in the logbook (GIN-9591 and GIN-9027). In the same publication, date GIN-9030 was reported to come from excavation block No. III. However, according to the field reports, this excavation block was not excavated in the area indicated (164-б). In these cases, it is logical to assume that the information from the logbook is more reliable because it is more detailed and precise than the information given in the publication. Vice versa, for dates taken from horse bones, the information published by L.D. Sulerzhitsky seems to be more reliable. In this case, the publication lists seven different squares for the seven horse bones ${ }^{14} \mathrm{C}$-dated, whereas only one square was noted for all these samples in the logbook. However, since these results may be a weighted average of specimens of different ages, the author does not consider it appropriate to use them in the spatial analysis of the distribution of ${ }^{14} \mathrm{C}$ dates.

Also noteworthy is the discrepancy between the depths of the majority of the samples and one sample with a date of 27,460 $\pm 310 \mathrm{BP}(\mathrm{OxA}-9039)$. While the counting of the depths of the arbitrary levels usually began with the appearance of the first finds (Bader 1978), sample OxA-9039 was obtained during the 1995 excavation, also conducted by N.O. Bader but this time using modern excavation methods. Thus, this sample has a three-dimensional control point, whereas the rest of the samples discussed here, as a whole, are referenced by arbitrary levels without exact depth.

Unfortunately, detailed archive data on the remaining seven dates, which were obtained in laboratories other than the one in Moscow, were not available to the author. Thus, the presented spatial analysis is based on the distribution of $22{ }^{14} \mathrm{C}$ dates. Information about the relative depth of a particular sample is indicated in 13 cases. In this regard, a number of the following assumptions should be understood to be a hypothesis based on the available archival data.

\section{RESULTS AND DISCUSSION}

All the direct ${ }^{14} \mathrm{C}$ values published to date from the Sungir site are summarized in Table 1 . The author calibrated the dates of the cultural layer using the IntCal09 data set (Reimer et al. 2009) and CalPal software (Weninger and Jöris 2008).

All in all, ${ }^{14} \mathrm{C}$ values range between $\sim 14,000$ and $30,000 \mathrm{BP}$. There are $40{ }^{14} \mathrm{C}$ dates from the cultural layer of the Sungir site run on animal bones, charcoal, and soil, and 20 dates on human bones from the burials. 


\begin{tabular}{|c|c|c|c|c|c|}
\hline Material & ${ }^{14} \mathrm{C}$ date $(\mathrm{BP})$ & Lab code & $\begin{array}{l}\text { Calendar age, } \\
\text { cal } \mathrm{BP}^{1}\end{array}$ & Location & Reference \\
\hline Bone, cultural layer & $14,600 \pm 600$ & GIN-14 & $17,782 \pm 657$ & - & Bader 1978: 64 \\
\hline $\begin{array}{l}\text { Soil underlying the } \\
\text { cultural layer }\end{array}$ & $16,200 \pm 400$ & GIN-15 & $19,477 \pm 517$ & - & Bader 1978: 64 \\
\hline C 1 , vertebra fragments & $19,160 \pm 270$ & AA-36473 & $22,967 \pm 358$ & - & Sulerzhitsky et al. 2000: 32 \\
\hline Charcoal interlayer & $19,780 \pm 80$ & LE-1058 & $23,663 \pm 933$ & - & Bader 1978: 64 \\
\hline Mammoth, femur & $20,360 \pm 900$ & GIN-9585 & $24,427 \pm 1,142$ & Ex. block I, 154-a & Sulerzhitsky et al. 2000: 30 \\
\hline Soil & $20,540 \pm 120$ & GIN-16 & $24,499 \pm 300$ & - & Bader 1978: 64 \\
\hline C 1 , vertebra & $21,310+240 /-250$ & GrA-21513 & $25,475 \pm 406$ & - & Kuzmin et al. 2004: 454 \\
\hline $\begin{array}{l}\text { Charcoal from the floor of } \\
\text { the burial / charcoal from } \\
\text { the hearth / charcoal from } \\
\text { the cultural layer }\end{array}$ & $21,800 \pm 1000$ & GIN-326a & $26,203 \pm 1,284$ & - & $\begin{array}{l}\text { Sulerzhitsky et al. 2000: } \\
\text { 32 / Sinitsyn and Praslov } \\
\text { 1997: } 60 \text { / Bader 1978: } 64\end{array}$ \\
\hline $\begin{array}{l}\text { Charcoal from the floor of } \\
\text { the burial / charcoal from } \\
\text { the hearth / charcoal from } \\
\text { the cultural layer }\end{array}$ & $22,500 \pm 600$ & GIN-326б & $26,970 \pm 823$ & - & $\begin{array}{l}\text { Sulerzhitsky et al. 2000: } \\
\text { 32 / Sinitsyn and Praslov } \\
\text { 1997: } 60 \text { / Bader 1978: } 64\end{array}$ \\
\hline Mammoth & $22,700 \pm 600$ & GIN-10887 & $27,157 \pm 809$ & - & Sulerzhitsky 2004: 111 \\
\hline C 1 , tibia fragments & $22,930 \pm 200$ & OxA-9036 & $27,530 \pm 442$ & - & Sulerzhitsky et al. 2000: 32 \\
\hline $\begin{array}{l}\text { Mammoth, radial } \\
\text { fragment }\end{array}$ & $23,600 \pm 500$ & GIN-8998 & $28,510 \pm 651$ & $\begin{array}{l}\text { Ex. block I, } \\
\text { arb. level 3, 164-м }\end{array}$ & Sulerzhitsky et al. 2000: 30 \\
\hline C 2, tibia fragments & $23,830 \pm 220$ & OxA-9037 & $28,737 \pm 423$ & - & Sulerzhitsky et al. 2000: 32 \\
\hline C 3 , tibia fragments & $24,100 \pm 240$ & OxA-9038 & $28,912 \pm 427$ & - & Sulerzhitsky et al. 2000: 32 \\
\hline C 3, rib & $24,170+120 /-130$ & GrA-28182 & $28,947 \pm 392$ & - & Kuzmin et al. 2004: 454 \\
\hline Deer & $24,430 \pm 400$ & $\begin{array}{l}\text { Gro-5446 / } \\
\text { GrN-5446 }\end{array}$ & $29,225 \pm 596$ & - & $\begin{array}{l}\text { Bader 1978: } 64 \text { / Sinitsyn } \\
\text { and Praslov 1997: } 60\end{array}$ \\
\hline C 3 , right tibia & $24,830 \pm 110$ & OxA-15754 & $29,859 \pm 302$ & - & Marom et al. 2012: 2 \\
\hline C 2 , right tibia & $25,020 \pm 120$ & OxA-15753 & $29,989 \pm 257$ & - & Marom et al. 2012: 2 \\
\hline C 3 , right tibia & $25,430 \pm 160$ & OxA-15751 & $30,276 \pm 318$ & - & Marom et al. 2012: 2 \\
\hline $\begin{array}{l}\text { Charcoal from the cultural } \\
\text { layer }\end{array}$ & $25,500 \pm 200$ & $\begin{array}{l}\text { Gro-5425 / } \\
\text { GrN-5425 }\end{array}$ & $30,416 \pm 404$ & - & $\begin{array}{l}\text { Bader 1978: } 64 \text { / Sinitsyn } \\
\text { and Praslov 1997: } 60\end{array}$ \\
\hline
\end{tabular}

Soil

Charcoal from the floor of the burial / charcoal from

the hearth / charcoal from

cultural layer

the burial / charcoal from

the hearth / charcoal from

the cultural laye

$22,930 \pm 200$

OxA-9036

fragment

C tibia fragments

C 3 , rib

C 3, right tibia

C 2, right tibia

Charcoal from the cultural

layer 


\begin{tabular}{|c|c|c|c|c|c|}
\hline Material & ${ }^{14} \mathrm{C}$ date (BP) & Lab code & $\begin{array}{l}\text { Calendar age, } \\
\text { cal } \mathrm{BP}^{1}\end{array}$ & Location & Reference \\
\hline Horse, 7 fragments & $25,740 \pm 600$ & GIN-9001 & $30,654 \pm 657$ & $\begin{array}{l}\text { 102-103-т; 165, 165, } \\
\text { 166, 166, 163-х-ф-у, } \\
\text { 163-х-ф-ц / Ex. block } \\
\text { II, arb. level 3, 150-д }\end{array}$ & $\begin{array}{l}\text { Sulerzhitsky et al. 2000: } \\
30 \text { / Logs records of } \\
\text { analyzes }\end{array}$ \\
\hline C 3 , humerus & $26,000 \pm 410$ & KIA-27007 & $30,951 \pm 440$ & - & $\begin{array}{l}\text { Dobrovolskaya et al. } \\
\text { 2012: } 100\end{array}$ \\
\hline Mammoth & $26,100 \pm 1000$ & GIN-10886 & $30,793 \pm 902$ & $\begin{array}{l}\text { Ex. block II, arb. } \\
\text { level 2, 164-уч }\end{array}$ & Sulerzhitsky 2004: 111 \\
\hline C 2, tibia & $26,190 \pm 120$ & GrA-34760 & $31,076 \pm 338$ & - & Kuzmin et al. 2004: 454 \\
\hline C 3 , rib fragments & $26,190 \pm 640$ & AA-36476 & $31,010 \pm 556$ & - & Sulerzhitsky et al. 2000: 32 \\
\hline C 2, left ribs & $26,200 \pm 640$ & AA-36475 & $31,016 \pm 555$ & - & Sulerzhitsky et al. 2000: 32 \\
\hline C 1, vertebra & $26,300+220 /-230$ & GrA-21507 & $31,132 \pm 368$ & - & Kuzmin et al. 2004: 454 \\
\hline Mammoth, femur & $26,300 \pm 260$ & GIN-8995 & $31,128 \pm 380$ & $\begin{array}{l}\text { Ex. block III, arb. } \\
\text { level 3, 142-a }\end{array}$ & Sulerzhitsky et al. 2000: 30 \\
\hline Horse, 5 fragments & $26,300 \pm 300$ & GIN-9034 & $31,125 \pm 392$ & $\begin{array}{l}\text { Ex. block III, 166-ж; } \\
\text { 151-з; 158-к; 158; } \\
\text { 138-л /Ex. block III, } \\
\text { arb. level 3, 158-к }\end{array}$ & $\begin{array}{l}\text { Sulerzhitsky et al. 2000: } \\
30 / \text { Logs records of } \\
\text { analyzes }\end{array}$ \\
\hline Mammoth, femur & $26,600 \pm 300$ & GIN-9030 & $31,302 \pm 398$ & $\begin{array}{l}\text { Ex. block I, arb. } \\
\text { level 1, 164-б }\end{array}$ & Sulerzhitsky et al. 2000: 30 \\
\hline Deer, vertebra & $26,900 \pm 260$ & GIN-9035 & $31,647 \pm 234$ & Ex. block III, 147-м & Sulerzhitsky et al. 2000: 30 \\
\hline Mammoth, tubular bone & $27,000 \pm 320$ & GIN-9591 & $31,713 \pm 256$ & Ex. block I, 152-б & Sulerzhitsky et al. 2000: 30 \\
\hline C 1 , femur & $27,050 \pm 210$ & KIA-27006 & $31,790 \pm 164$ & - & $\begin{array}{l}\text { Dobrovolskaya et al. } \\
\text { 2012: } 100\end{array}$ \\
\hline Mammoth, ulna & $27,200 \pm 400$ & GIN-9027 & $31,906 \pm 310$ & Ex. block I, 157-c & Sulerzhitsky et al. 2000: 30 \\
\hline Mammoth, femur & $27,200 \pm 500$ & GIN-9586 & $31,901 \pm 435$ & $\begin{array}{l}\text { Ex. block III, arb. } \\
\text { level } 3,157-c\end{array}$ & Sulerzhitsky et al. 2000: 30 \\
\hline Mammoth & $27,200 \pm 700$ & GIN-10885 & $31,862 \pm 696$ & Ex. block II, 169-c & Sulerzhitsky 2004: 111 \\
\hline
\end{tabular}




\begin{tabular}{|c|c|c|c|c|c|}
\hline Material & ${ }^{14} \mathrm{C}$ date (BP) & Lab code & $\begin{array}{l}\text { Calendar age, } \\
\text { cal } \mathrm{BP}^{1}\end{array}$ & Location & Reference \\
\hline C 2 , right ribs & $27,210 \pm 710$ & AA-36474 & $31,874 \pm 705$ & - & Sulerzhitsky et al. 2000: 32 \\
\hline Deer, vertebra & $27,260 \pm 500$ & GIN-9036 & $31,982 \pm 432$ & $\begin{array}{l}\text { Ex. block II, } \\
\text { line B-ж }\end{array}$ & Sulerzhitsky et al. 2000: 30 \\
\hline Horse, 6 fragments & $27,400 \pm 400$ & GIN-9033 & $32,134 \pm 532$ & $\begin{array}{l}\text { Ex. block II, 132-п; } \\
\text { 159-160-с-т; } \\
\text { 147-ц / Ex. block I, } \\
\text { 127-а; 147-с-т }\end{array}$ & $\begin{array}{l}\text { Sulerzhitsky et al. 2000: } \\
30 \text { / Logs records of } \\
\text { analyzes }\end{array}$ \\
\hline Mammoth, tubular bone & $27,460 \pm 310$ & OxA-9039 & $32,123 \pm 292$ & $\begin{array}{l}\text { Ex. block III, } \\
\text { arb. level 4, depth } \\
137,3 \mathrm{~cm}, 162-\mathrm{c}\end{array}$ & Sulerzhitsky et al. $2000: 30$ \\
\hline Mammoth, femur & $27,630 \pm 280$ & GIN-9031 & $32,251 \pm 316$ & $\begin{array}{c}\text { Ex. block III, } \\
\text { arb. level 2, 118-Г }\end{array}$ & Sulerzhitsky et al. 2000: 30 \\
\hline Mammoth, humerus & $27,700 \pm 500$ & GIN-5880 & $32,369 \pm 453$ & - & $\begin{array}{l}\text { Sinitsyn and Praslov } \\
\text { 1997: } 60\end{array}$ \\
\hline Mammoth & $27,700 \pm 600$ & GIN-10888 & $32,393 \pm 524$ & Ex. block I, 152-б & Sulerzhitsky 2004: 111 \\
\hline Mammoth, vertebra & $27,800 \pm 600$ & GIN-9588 & $32,469 \pm 531$ & Ex. block I, 109-B & Sulerzhitsky et al. $2000: 30$ \\
\hline Mammoth, femur & $28,000 \pm 250$ & GIN-8997 & $32,498 \pm 335$ & Ex. block I, 151-ח & Sulerzhitsky et al. 2000: 30 \\
\hline Mammoth, femur & $28,000 \pm 300$ & GIN-9029 & $32,510 \pm 360$ & $\begin{array}{c}\text { Ex. block I, } \\
\text { arb. level 2, 159-a }\end{array}$ & Sulerzhitsky et al. 2000: 30 \\
\hline Mammoth, humerus & $28,120 \pm 170$ & GIN-8999 & $32,568 \pm 309$ & $\begin{array}{l}\text { Ex. block III, depth } \\
\text { 33-62 cm, 150-д }\end{array}$ & Sulerzhitsky et al. 2000: 30 \\
\hline Mammoth, femur & $28,130 \pm 370$ & GIN-8996 & $32,625 \pm 414$ & $\begin{array}{c}\text { Ex. block I, } \\
132-133-л\end{array}$ & Sulerzhitsky et al. 2000: 30 \\
\hline Mammoth & $28,200 \pm 800$ & GIN-10883 & $32,824 \pm 728$ & - & Sulerzhitsky 2004: 111 \\
\hline Mammoth, femur & $28,350 \pm 200$ & GIN-9032 & $32,752 \pm 348$ & $\begin{array}{c}\text { Ex. block I, } \\
\text { arb. level 1, 170-pc }\end{array}$ & Sulerzhitsky et al. 2000: 30 \\
\hline Mammoth & $28,600 \pm 600$ & GIN-10884 & $33,072 \pm 645$ & $\begin{array}{c}\text { Ex. block III, } \\
\text { arb. level 1, 132-г }\end{array}$ & Sulerzhitsky 2004: 111 \\
\hline
\end{tabular}


Table 1 (Continued)

\begin{tabular}{|c|c|c|c|c|c|}
\hline Material & ${ }^{14} \mathrm{C}$ date $(\mathrm{BP})$ & Lab code & $\begin{array}{l}\text { Calendar age, } \\
\text { cal } \mathrm{BP}^{1}\end{array}$ & Location & Reference \\
\hline Mammoth & $28,700 \pm 1000$ & GIN-10889 & $33,133 \pm 845$ & $\begin{array}{c}\text { Ex. block II, } \\
\text { arb. level 3, 161-H }\end{array}$ & Sulerzhitsky 2004: 111 \\
\hline Mammoth, ulna & $28,800 \pm 240$ & GIN-9028 & $33,384 \pm 388$ & $\begin{array}{l}\text { Ex. block II, } \\
\text { arb. level 2, 144-пा }\end{array}$ & Sulerzhitsky et al. $2000: 30$ \\
\hline C 1 & $28,890 \pm 430$ & OxA-X-2464-12 & $33,326 \pm 518$ & - & $\begin{array}{l}\text { Nalawade-Chavan et al. } \\
\text { 2013: } 4\end{array}$ \\
\hline Mammoth & $29,450 \pm 180$ & OxA-15755 & $33,819 \pm 308$ & - & Marom et al. 2012: 2 \\
\hline Mammoth & $29,640 \pm 180$ & OxA-15752 & $33,973 \pm 271$ & - & Marom et al. 2012: 2 \\
\hline C 4 & $29,820 \pm 280$ & OxA-X-2462-52 & $34,082 \pm 282$ & - & $\begin{array}{l}\text { Nalawade-Chavan et al. } \\
\text { 2013: } 4\end{array}$ \\
\hline C 3 , right tibia & $30,000 \pm 550$ & OxX-2395-7 & $34,166 \pm 488$ & - & Marom et al. 2012: 2 \\
\hline Mammoth & $30,100 \pm 400$ & OxX-2395-8 & $34,300 \pm 311$ & - & Marom et al. 2012: 2 \\
\hline C 2, right tibia & $30,100 \pm 550$ & OxX-2395-6 & $34,294 \pm 493$ & - & Marom et al. 2012: 2 \\
\hline
\end{tabular}

combined. 
It must be mentioned that the youngest ${ }^{14} \mathrm{C}$ values up to $20,000 \mathrm{BP}$ were obtained in the laboratory of the Geological Institute of the USSR Academy of Sciences when the ${ }^{14} \mathrm{C}$ dating method was in an early stage of development. This has also been clearly stated by O.N. Bader (1978), who interpreted these dates as too young.

${ }^{14} \mathrm{C}$ samples of tibiae found in the human burials $\mathrm{S} 1, \mathrm{~S} 2$, and $\mathrm{S} 3$ were measured at the University of Oxford and range from 22,930 $\pm 200 \mathrm{BP}$ (OxA-9036) to 24,100 $\pm 240 \mathrm{BP}$ (OxA-9038). These dates contradict ${ }^{14} \mathrm{C}$ dates obtained by the ${ }^{14} \mathrm{C}$ laboratory of the University of Arizona on rib fragments from the same burials, which fall into a range from $19,160 \pm 270 \mathrm{BP}$ (AA-36473) to 26,200 $\pm 640 \mathrm{BP}$ (AA-36475; Alekseeva and Bader 2000). These ${ }^{14} \mathrm{C}$ dates have no correlation with each other; at the same time ${ }^{14} \mathrm{C}$ dates $22,930 \pm 200 \mathrm{BP}$ (OxA-9036) and 19,160 $\pm 270 \mathrm{BP}$ (AA-36473) contradict most of the cultural layer dates (Alekseeva and Bader 2000). It was noted by Kuzmin et al. (2004, 2014) that there was a substantial discrepancy in the results and that a reanalysis was needed. AMS ${ }^{14} \mathrm{C}$ measurements of the $\mathrm{S} 1$ individual on a sample from the femur and of the $\mathrm{S} 3$ individual's on a humerus were conducted in the Leibniz Laboratory at the Christian-Albrecht-University of Kiel, Germany. The dates are 27,050 $\pm 210 \mathrm{BP}$ (KIA27006) and 26,000 \pm 410 BP (KIA-27007), respectively (Dobrovolskaya et al. 2012).

Because results obtained for the human burials by the Oxford, Arizona, and Kiel labs were "highly inconsistent, both between the laboratories and between the different individuals dated," there was an attempt to carry out the analysis using the AMS hydroxyproline dating method (Marom et al. 2012: 6879). The results obtained from samples from the double burial (S 2, S 3) and a mammoth bone found in the cultural layer were published in 2012: 30,100 $\pm 550 \mathrm{BP}$ (S 2, OxX-2395-6), 30,000 $\pm 550 \mathrm{BP}$ (S 3, OxX-2395-7), and $30,100 \pm 400 \mathrm{BP}$ (mammoth bone, OxX-2395-8), respectively (Marom et al. 2012). The AMS dates are in good agreement to each other, and according to the authors of the study, reflect the actual age of the investigated burials (Marom et al. 2012). In 2013, additional AMS hydroxyproline dates for the burials $\mathrm{S} 1$ and $\mathrm{S} \mathrm{4}$, measured in the Oxford laboratory, were published: 28,890 $\pm 430 \mathrm{BP}$ (OxA-X-2464-12) and 29,820 $280 \mathrm{BP}$ (OxA-X-2462-52), respectively (Nalawade-Chavan et al. 2013). Allthough Nalawade-Chavan et al. (2013) emphasize that the specimens have traces of impurity resulting from museum conservation, they still conclude that the results, if compared to the results published in 2012, are reliable (Nalawade-Chavan et al. 2013: 5).

Therefore, the rather reliable AMS hydroxyproline dates for S 1, S 2, S 3, S 4 and of the mammoth bone indicate that the samples' ages are approximately between 28,000 and $30,000 \mathrm{BP}$ (or 31,000 and 34,000 cal BP).

There are three ${ }^{14} \mathrm{C}$ values from horse bones: $25,740 \pm 600 \mathrm{BP}$ (GIN-9001), 26,300 $\pm 300 \mathrm{BP}$ (GIN-9034), and 27,400 $\pm 400 \mathrm{BP}$ (GIN-9033). It is not clear how far the single specimens of bulk samples were measured here, so the results may be a weighted average of specimens of different ages (Alekseeva and Bader 2000: 30). Moreover, the sample for the date of $25,740 \pm 600 \mathrm{BP}$ (GIN-9001) was taken from a mixed layer and is not connected with archaeological complexes (Alekseeva and Bader 2000: 34).

In contrast to the new dates on human bones, but comparable to the horse remains dates, the $27{ }^{14} \mathrm{C}$ dates on mammoth bones, which range from 20,360 to $30,100 \mathrm{BP}$, also raise questions with regard to their reliability. It is known that prehistoric hunter-gatherers used bone as fuel to run fireplaces and raw material for tool production as well as the construction of dwellings, 
obtaining them not only from hunting but also from gathering fossil bones (e.g. Kuzmin et al. 2001). Therefore, the dates on mammoth bones found at Sungir may indicate the death of the animal, but do not necessarily correlate with the age of human activities at the site (e.g., Sulerzhitskiy 2004).

There are three ${ }^{14} \mathrm{C}$ values run on reindeer bone, which date to $24,430 \pm 400 \mathrm{BP}$ (GrN-5446), $26,900 \pm 260 \mathrm{BP}$ (GIN-9035), and 27,260 $\pm 500 \mathrm{BP}$ (GIN-9036). They appear to be directly connected with human activities and therefore more accurate than the other dates on animal bones, as most of the faunal remains at Sungir come from reindeer (Gromov 1966; Alexeeva 1998). V.I. Gromov underlines that "The debris [of reindeer; comment by the author] contains skull fragments and all bones of the postcranial skeleton." He also states that "Many bones have traces of manmade splitting for brain extraction" (Gromov 1966: 78; translation by the author). In addition, reindeer antler was used extensively for tool production. In sum, 28 items or $16 \%$ of all hard organic raw material tools found in the cultural layer were made of antler (Soldatova 2014). Therefore, in the author's opinion, ${ }^{14} \mathrm{C}$ ages of the reindeer bones are fairly reliable. The calendar age range for those bones falls between $\sim 29,000$ and 31,000 cal BP.

Four ${ }^{14} \mathrm{C}$ dates were obtained from charcoal samples: 19,780 $\pm 80 \mathrm{BP}$ (LE-1058), $21,800 \pm 1000 \mathrm{BP}(\mathrm{GIN}-326 \mathrm{a}), 22,500 \pm 600 \mathrm{BP}(\mathrm{GIN}-326 \mathrm{~b})$, and 25,500 $\pm 200 \mathrm{BP}(\mathrm{GrN}-5425)$. The first, $19,780 \pm 80 \mathrm{BP}$, was measured in a laboratory at the Leningrad department of the Institute of Archaeology of the USSR Academy of Sciences, and, in O.N. Bader's opinion, did not prove to be accurate (Bader 1978: 65). The charcoal material for the other two results is equally unclear because the exact provinience is uncertain. Due to the information available, the samples were either taken from the cultural layer, a hearth, or the floor of the burial (Bader 1978: 64; Sinitsyn and Praslov 1997: 60; Sulerzhitskiy et al. 2000: 32). With regard to dates on charcoal, it appears that only the date of $25,500 \pm 200 \mathrm{BP}(\mathrm{GrN}-5425){ }^{14} \mathrm{C}$ is reliable.

In the course of the current study, the author analyzed the spatial distribution of ${ }^{14} \mathrm{C}$-dated samples from animal bones. The spatial distribution of the dated samples is shown in Figure 3. All in all, spatial information was available for 22 samples: 21 samples on mammoth bones and one sample on a deer bone. Apart from the fact that the presence of mammoth remains at the site might go back to the gathering of fossil bones, one can say that the results so far for ${ }^{14} \mathrm{C}$ dating at Sungir essentially do not correlate with evident structures, e.g. fireplaces, fire and ritual pits, large accumulations of bones, etc.

Excavation block No. I is the best dated. In sum, $11{ }^{14} \mathrm{C}$ dates were obtained from samples from the cultural layer. At the same time, this area is relatively poor in finds (Bader 1978; Soldatova 2012). The main array of dates covers the period from $26,600 \pm 300$ to $28,350 \pm 200 \mathrm{BP}$. Two dates show a younger age of 20,360 \pm 900 and 23,600 $\pm 500 \mathrm{BP}$. In contrast to excavation block No. I, excavation block No. II has only four ${ }^{14} \mathrm{C}$ dates (without considering the results of dating burials), which fall in a range between $25,740 \pm 600$ and 28,800 \pm 240 BP. Finally, excavation block No. III has seven ${ }^{14} \mathrm{C}$ dates, which cover a period from $26,300 \pm 260$ to $28,600 \pm 600 \mathrm{BP}$.

As far as the vertical distribution of the ${ }^{14} \mathrm{C}$-dated samples is concerned, the available data suggests that most of the samples came from arbitrary levels 1 to 3 , which correspond to a depth of about 20 to $60 \mathrm{~cm}$ "from the beginning of the finds" (Bader 1978). It should be noted that arbitrary levels below this level were also rich in archaeological finds (Bader 1978; Soldatova 2012). Therefore, it must be assumed that the results of the ${ }^{14} \mathrm{C}$ dating in 


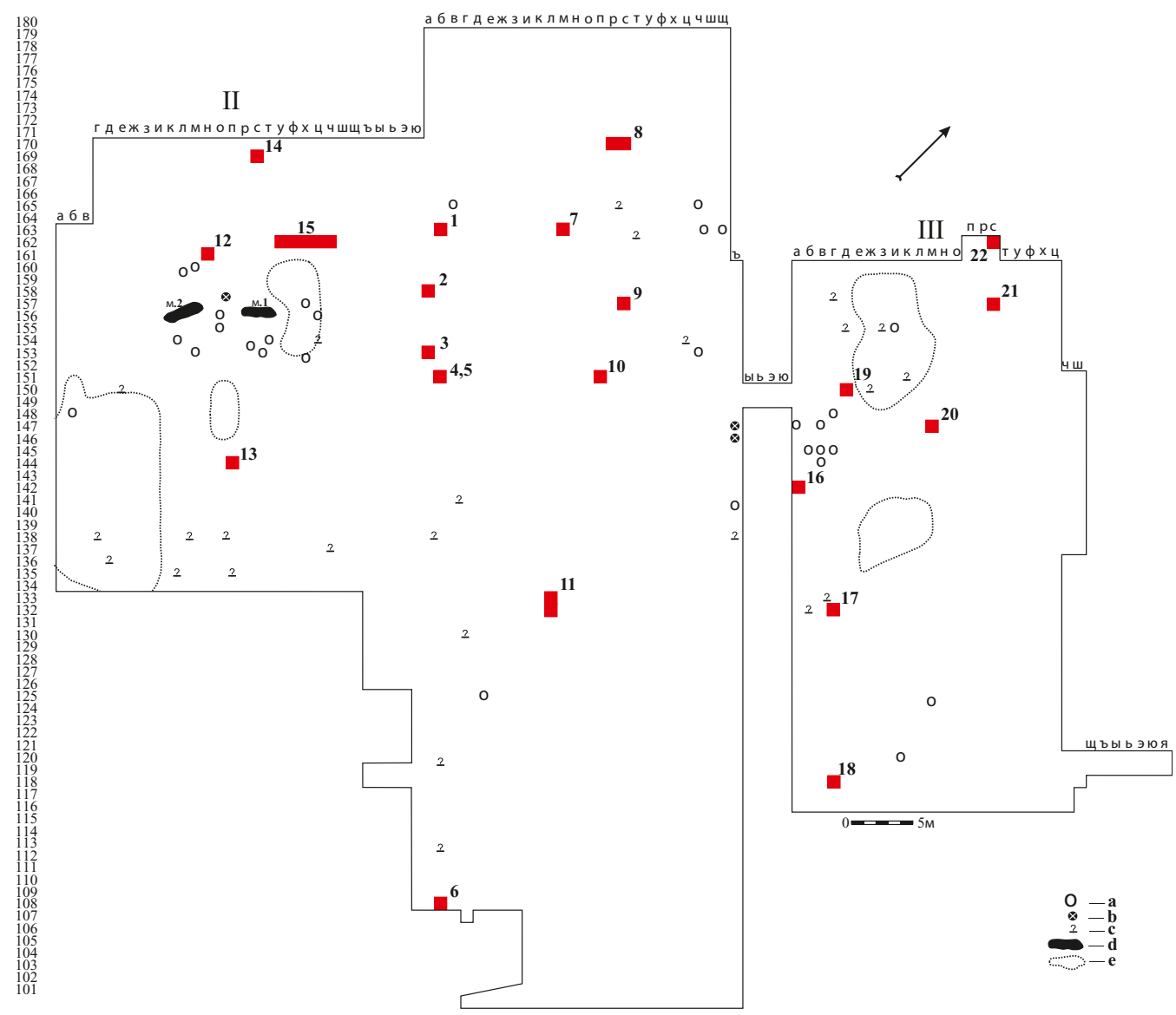

Figure 3 Spatial distribution of the samples of ${ }^{14} \mathrm{C}$ dating. a) firepit; b) ritual pit; c) fireplaces; d) grave; e) large accumulations of bones. Excavation block No. I: 1) 26,600 4300 BP (GIN-9030); 2) 28,000 \pm 300 BP (GIN-9029); 3 )

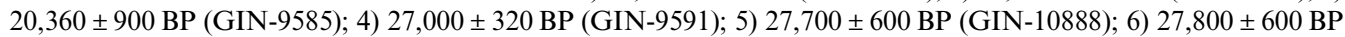
(GIN-9588); 7) 23,600 \pm 500 BP (GIN-8998); 8) 28,350 \pm 200 BP (GIN-9032); 9) 27,200 \pm 400 BP (GIN-9027); 10) $28,000 \pm 250 \mathrm{BP}(\mathrm{GIN}-8997) ; 11) 28,130 \pm 370 \mathrm{BP}(\mathrm{GIN}-8996)$; excavation block No. II: 12) $28,700 \pm 1,000 \mathrm{BP}$

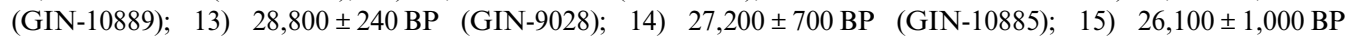
(GIN-10886); excavation block No. III: 16) 26,300 260 BP (GIN-8995); 17) 28,600 \pm 600 BP (GIN-10884); 18)

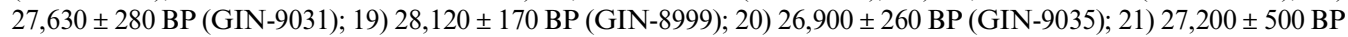
(GIN-9586); 22) 27,460 \pm 310 BP (OxA-9039).

general only poorly correlate with the frequencies of archaeological finds in the artificial arbitrary levels of the cultural layer.

In addition, there are cases in which the dates are in contradiction with the stratigraphical sequence For example, for excavation block No. I, three dates yield information about their stratigraphical context: one sample from arbitrary level 1 is dated to $26,600 \pm 300 \mathrm{BP}$, another sample from arbitrary level 2 below dates to $28,000 \pm 300 \mathrm{BP}$, and a third sample from the lowermost arbitrary level 3 with a date of $23,600 \pm 500 \mathrm{BP}$ is the youngest. Excavation block No. III shows a similar picture (Figure 4). The dates from excavation block No. II seem to be in stratigraphical order: arbitrary level 2 dates to $26,100 \pm 1000 \mathrm{BP}$ 
No. I
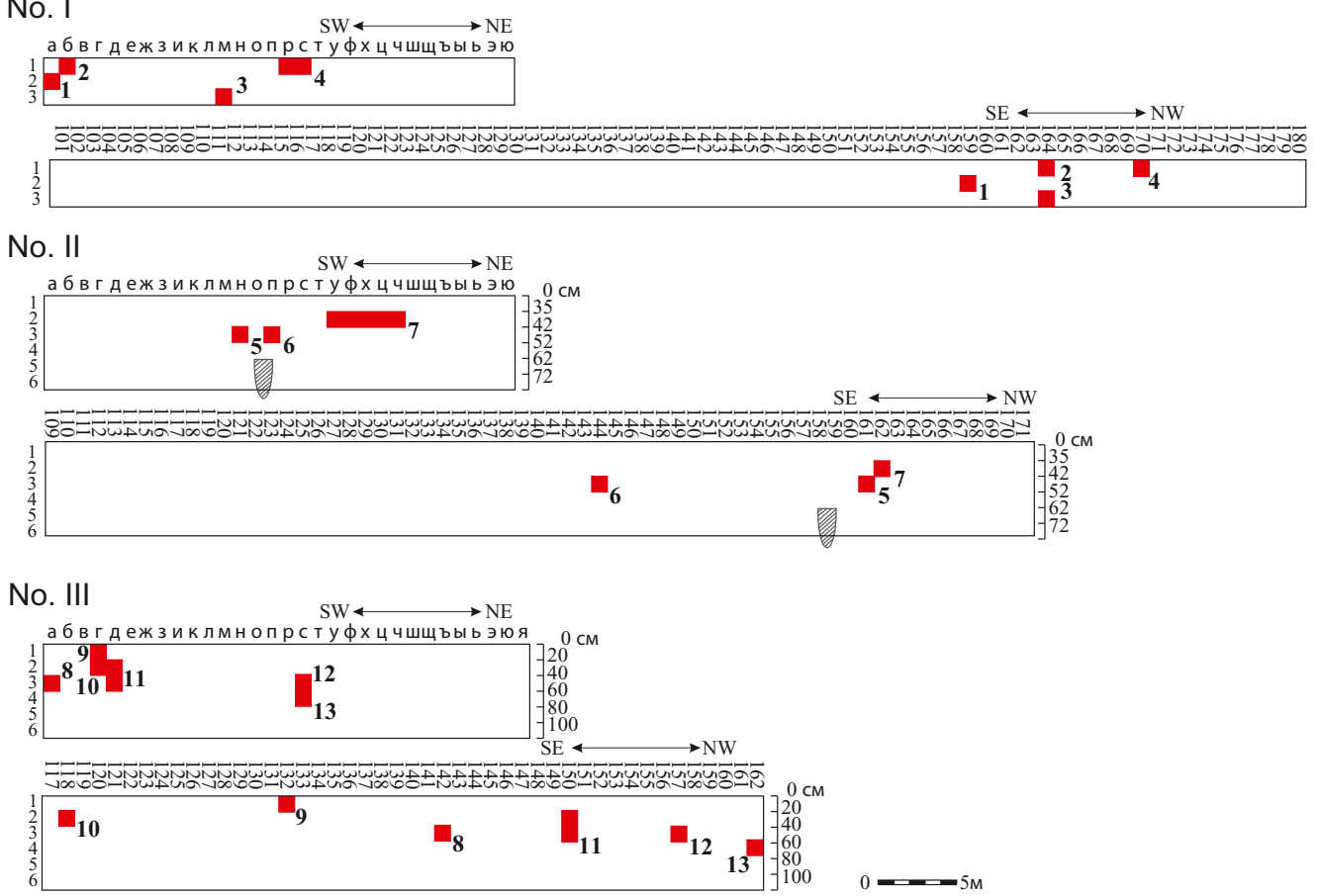

Figure 4 Stratigraphic distribution of the samples of ${ }^{14} \mathrm{C}$ dating. Excavation block No. I: 1) $28,000 \pm 300 \mathrm{BP}$ (GIN-9029); 2) 26,600 2300 BP (GIN-9030); 3) 23,600 \pm 500 BP (GIN-8998); 4) 28,350 \pm 200 BP (GIN-9032); excavation block No. II: 5) 28,700 $\pm 1,000 \mathrm{BP}$ (GIN-10889); 6) 28,800 $\pm 240 \mathrm{BP}$ (GIN-9028); 7) 26,100 $\pm 1,000 \mathrm{BP}$ (GIN-10886); excavation block No. III: 8) 26,300 \pm 260 BP (GIN-8995); 9) 28,600 \pm 600 BP (GIN-10884); 10) $27,630 \pm 280 \mathrm{BP}(\mathrm{GIN}-9031) ; 11) 28,120 \pm 170 \mathrm{BP}(\mathrm{GIN}-8999) ; 12)$ 27,200 $\pm 500 \mathrm{BP}(\mathrm{GIN}-9586) ; 13) 27,460 \pm 310 \mathrm{BP}$ (OxA-9039).

and arbitrary level 3 delivered ${ }^{14} \mathrm{C}$ ages of $28,700 \pm 1000$ and $28,800 \pm 240 \mathrm{BP}$. Whereas the low number of samples calls for caution, the inverse order in excavation block No. I indicates the activity of solifluction and/or slope processes, which lead to a mixing of the cultural layer.

Once again, I would like to point out the insufficiency of archival materials and the presumptive nature of the statements made above.

\section{CONCLUSIONS}

Consequently, despite the significant number of $60{ }^{14} \mathrm{C}$ dates, there are still many open questions concerning the age of the Sungir site.

The available ${ }^{14} \mathrm{C}$ dates do not allow for an exact determination of the period of existence of the Sungir site, nor do they enable us to clearly distinguish different occupations. On the other hand, it must be emphasized that a comprehensive analysis of the archaeological items made from hard, organic raw materials, including a technical-typological and spatial analysis of bone, antler, and ivory objects, did not give any argument for the existence of different cultural layers and/or a long chronology of site use. The presented spatial and stratigraphic data is certainly incomplete due to the lack of archive data. However, the results presented here still allow one to draw some general conclusions: (1) the stratigraphic analysis of the 


\section{T Soldatova}

distribution of dates argues for a mixed character of the cultural layer of the Sungir, and (2) the results of the horizontal distribution of the dates showed the absence of dates associated with the evident features (fire places, pits, etc.) of the cultural layer.

To solve the problems described above, it is necessary to conduct new ${ }^{14} \mathrm{C}$ datings from the cultural layer of Sungir. In the recent past, the most attention was paid to dating samples from the burials, which are connected both with their world value and the contradictory results of older datings. However, for a better understanding of the cultural layer of the site, a series of ${ }^{14} \mathrm{C}$ dates should be obtained directly from the cultural layer. From the author's point of view, samples from all arbitrary levels of a selected representative yet undisturbed area of Sungir should be used. In addition, it would be important to collect more detailed information about the excavations in which burials were discovered in order to better correlate the burials with the cultural layer.

In general, material for new ${ }^{14} \mathrm{C}$ dates would be available: faunal remains are stored in the Vernadsky State Geological Museum, at the Paleontological Institute of the Russian Academy of Sciences (collection from 1986) and in the Vladimir-Suzdal Museum-Reserve (excavations from the 2000s). In addition, reference samples are hosted in the Geological Institute of the Russian Academy of Sciences in Moscow and in the Zoological Institute of the Russian Academy of Sciences in St. Petersburg. Finally, there is a collection of bone, antler, and ivory products from Sungir at the Vladimir-Suzdal Museum-Reserve. Among these are items with a clear reference to arbitrary levels and square meters of the excavations that would allow for sampling stratigraphical sequences in areas with evident features and high frequencies of finds. Perhaps, in light of a new series of dates, it will be possible to distinguish the presence of several cultural layers, the impact of solifluction processes, and the chronological position of the Sungir site.

\section{ACKNOWLEDGMENTS}

I am grateful to Roman Nechushkin (Geological Institute, Russian Academy of Sciences, Moscow) for assistance with the provision of data from the logged records of analyses. I also want to thank Prof. Dr. Thorsten Uthmeier (Institut für Ur- und Frühgeschichte, Friedrich-Alexander-Universität Erlangen-Nürnberg) for accepting and taking time to supervise the work and showing his interest by providing valuable comments, language editing, and proofreading. I acknowledge the two anonymous reviewers for their comments.

\section{REFERENCES}

Alekseeva LI. 1998. Okhotnichya fauna stoyanki Sungir [The prey fauna of the Sungir site]. In: Bader NO, editor. Pozdnepaleoliticheskoe Poselenie Sungir (Pogrebeniya i Prirodnaya Sreda). Moscow: Nauchny Mir Publ. p. 240-257. In Russian.

Alekseeva TI, Bader NO, editors. 2000. Homo Sungirensis. Upper Palaeolithic man: ecological and evolutionary aspects of the investigation. Moscow: Nauchny Mir Publ. 468 p. In Russian with English abstract.

Bader NO, editor. 1998. Pozdnepaleoliticheskoe Poselenie Sungir (Pogrebeniya I Prirodnaya Sreda) [Upper Paleolithic site Sungir (graves

and environment)]. Moscow: Nauchny Mir Publ. 272 p. In Russian.

Bader ON. 1978. Sungir. Verchnepaleoliticheskaja Stojanka [The Sungir site. An Upper Paleolithic Site]. Moscow: Nauka Publ. 271 p. In Russian.

Dobrovolskaya M, Richards MP, Trinkaus E. 2012. Direct radiocarbon dates for the mid Upper Paleolithic (Eastern Gravettian) burials from Sunghir, Russia. Bulletins et Mémoires de la Société d'Anthropologie de Paris 24:96-102.

Grigoriev GP. 1990. Sungir. ERAUL 42:137-139.

Gromov VI. 1966. Fauna stoyanki Sungir [Fauna of the Sungir site]. In: Sukachev VN, Gromov VI, Bader ON, editors. Verhnepaleoliticheskaya 
stoyanka Sungir [The Upper Paleolithic site Sungir]. Moscow: Nauka Publ. p. 74-78. In Russian.

Kaverzneva ED. 1985. Stratigrafiya stoyanki Sungir po statisticheskim dannym [Stratigraphy of the Sungir site according to statistical data]. Trudy GIM 60. p. 35-47. In Russian.

Kaverzneva ED. 2004. The characteristic of the station Sungir cultural deposit with the regard for the permafrost deformations. Rossiiskaya Arkheologiya 3:5-19. In Russian with English abstract.

Kuzmin YV, Burr GS, Jull AJT, Sulerzhitsky LD. 2004. AMS ${ }^{14} \mathrm{C}$ age of the Upper Palaeolithic skeletons from Sungir site, Central Russian Plain. Nuclear Instruments and Methods in Physics Research B 223-224:731-734.

Kuzmin YV, Orlova LA, Stuart AJ, Zenin VN, Dementiev VN. 2001 Human-mammoth (Mammuthus primigenius Blumenbach) interrelationships in the Palaeolithic of Siberia: a review of current knowledge. Terra degli elefanti Congresso internazionale [The world of elephants]. p. 714-717.

Kuzmin YV, van Der Plicht J, Sulerzhitsky LD. 2014. Puzzling ${ }^{14} \mathrm{C}$ dates for Upper Paleolithic site of Sungir. Radiocarbon 56(2):451-459.

Lavrushin YUA, Spiridonova EA. 1998. Geologopaleoehkologicheskie sobytiya pozdnego plejstocena $\mathrm{v}$ rajone paleoliticheskogo poseleniya Sungir [Geological-paleoecological events and the Late Pleistocene occurrences in the area of the Paleolithic site of Sungir]. In: Bader NO, editor. Pozdnepaleoliticheskoe Poselenie Sungir (Pogrebeniya i Prirodnaya Sreda). Moscow: Nauchny Mir Publ. p. 189-218. In Russian.

Marom A, McCullagh JSO, Higham TFG, Sinitsyn AA, Hedges REM. 2012. Single amino acid radiocarbon dating of Upper Paleolithic modern humans. Proceedings of the National Academy of Sciences of the USA 109(18): 6878-6881.

Nalawade-Chavan S, McCullagh J, Hedges R. 2013. New hydroxyproline radiocarbon dates from Sungir, Russia, confirm Early Mid Upper Palaeolithic burials in Eurasia. Public Library of Science 9:1:e76896.

Reimer PJ, Baillie MGL, Bard E, Bayliss A, Beck JW, Blackwell PG, Bronk Ramsey C, Buck CE, Burr GS, Edwards RL, Friedrich M, Grootes PM, Guilderson TP, Hajdas I, Heaton TJ, Hogg AG, Hughen KA, Kaiser KF, Kromer B, McCormac FG, Manning SW, Reimer RW, Richards DA, Southon JR, Talamo S, Turney CSM, van der Plicht J, Weyhenmeyer CE. 2009. IntCal09 and Marine09 radiocarbon age calibration curves, 0-50,000 years cal BP. Radiocarbon 51(4):1111-1150.

Seleznyov AB. 2004. Stoyanka Sungir: voprosy organizacii zhilogo prostranstva [The Sungir site: the questions of living space organization]. Moscow: TAUS Publ. 60 p. In Russian.

Sinitsyn AA, Praslov ND. 1997. Radiouglerodnaya hronologiya paleolita Vostochnoj Evropy i Severnoj Azii. Problemy i perspektivy [Radiocarbon Chronology of the Paleolithic of Eastern Europe and Northern Asia. Problems and Perspectives]. Saint-Petersburg: IIMK RAN Publ. 143 p. In Russian.

Soldatova TE. 2012. A planigraphic study of the bone industry at Sungir Upper Paleolithic site. Rossiiskaya Arkheologiya 2:52-9. In Russian with English abstract.

Soldatova TE. 2014. A study of antler tools from Sungir, Russia: preliminary results. Hugo Obermaier - Gesellschaft für Erforschung des Eiszeitalters und der Steinzeit e.V. 56. Jahrestagung in Braunschweig und Schöningen, 22-26 April 2014, inprint GmbH, D-91058 Erlangen. p. $44-45$.

Soldatova TE. 2017. Characterizing the Early Upper Paleolithic bone industry from Sungir. In: Otte M, Sinitsin A, Vasiliev S, editors. The Sungirian and Streletskian in the context of the Eastern European Early Upper Paleolithic. Acts of the Conference of the UISPP Commission 8 in Saint-Petersbourg. Etudes et Researches Archeologiques de l'Universite de Liege. 147:85-91.

Sulerzhitsky LD, Pettitt P, Bader NO. 2000. Radiocarbon dates of the remains from the settlement Sunghir. In: Alekseeva TI, Bader NO, editors. Homo sungirensis. Upper Palaeolithic man: ecological and evolutionary aspects of the investigation. Moscow: Nauchny Mir Publ. p. 30-34. In Russian with English abstract.

Sulerzhitsky LD. 2004. The chronological span of some Late Palaeolithic sites according to the radiocarbon dating of the bones of megafauna. Rossiiskaya Arkheologiya 3:103-12. In Russian with English abstract.

Weninger B, Jöris O. 2008. A ${ }^{14} \mathrm{C}$ age calibration curve for the last $60 \mathrm{ka}$ : the Greenland-Hulu U/Th timescale and its impact on understanding the Middle to Upper Paleolithic transition in Western Eurasia. Journal of Human Evolution 55(5):772-781.

White R. 1993. Technological and social dimensions of "Aurignacian Age" body ornaments across Europe. In: Knecht H, Pike-Tay A, White R, editors. Before Lascaux. CRC Press. p. 277-99. 